\title{
The Development of Mathematics Comics Media on Linear Equations and Linear Inequalities of One Variable
}

\author{
Nana Sepriyanti ${ }^{1}$, Cisil Tapia ${ }^{2}$ \\ ${ }^{1,2}$ Tadris Matematika, Fakultas Tarbiyah dan Keguruan, IAIN Imam Bonjol Padang, Indonesia
}

\begin{abstract}
This development research was aimed to produce mathematics comics media which valid and practical. This research was a research and development employing the 4-D model by Thiagarajan \& Semmel (1974). The model consisted of four development stages, namely define, design, develop and disseminate. The research instruments were validation sheets and practicality sheets. The data were analyzed by grouping the data based on the product qualification. The calculations were made to obtain mean scores classified into categories in the Likert scale assessment. The validity of product can be seen from the result of experts validation which show that the product was valid $(86.25 \%)$. The practicality of product can be seen from the result of the teacher and students practicality assessment sheet which show that the product was in a practical category $(90.04 \%)$. Thus, it can be concluded that the mathematics comics media on linear equations and linear inequalities of one variable was valid and very practical to be used as a medium of learning in mathematics.
\end{abstract}

\section{INTRODUCTION}

Mathematics is one of subject with a vital role in education. Mathematics learning consists of skill of knowledge, concept, principle or procedures instructed to the students in steps. It is due to mathematics is not an unbound sequence of knowledge. It implies that, learning mathematics may help students to comprehend other subjects. Nowadays, mathematics becomes a nightmare for many students and comes first among the lessons that are considered difficult to learn. Educators have a great responsibility in this respect. The most important one of these responsibilities is to identify the learning difficulties which are experienced about the lesson to be given and to take necessary precautions in view of these identified difficulties. Although covering a very large scope, learning difficulty in mathematics means a number of inadequacies particular to this field (Durmuş, 2007)

\footnotetext{
${ }^{1}$ IAIN Imam Bonjol Padang, Indonesia: munzilatululya@yahoo.com

2 IAIN Imam Bonjol Padang, Indonesia: cisiltapia@yahoo.com
} 
The objective of mathematics education is surely to make students actualize learning in the highest level. However, the fact that the vast majority of the students experience difficulties while a few of them actualize learning is considered a reality of life (Tall \& Razali, 1993). To identify and eliminate these experienced difficulties; to assist and guide the students during learning process is not only a requirement of modern education but also among the responsibilities of teachers (Ersoy \& Ardahan, 2003). Tall \& Razali (1993) stated the reasons for the learning difficulties of students generally as follows: (i)learning the basic concepts in adequately, (ii) inadequacy in formulizing verbal problems mathematically, (iii) insufficiency in algebraic, geometric and trigonometric skills. On scrutinizing the related literature, it has been found out that educators carried out researches on varied learning difficulties students experience in mathematics beginning from the preschool period up to university level and researches that would help eliminate these difficulties (Coşkun, 2008; Durmuş, 2007; Çetinkaya \& Ersoy 2009; Harel, 1989; Keşan, Kaya and Güvercin, 2010; Özmantar, Bingölbali \& Akkoç, 2008; Rasmussen, 1998; Tall \& Razali, 1993; Ural, 2006).

Baştürk (2009) observed that the mistakes made by the students in the concept of absolute value umerous and varied; and the most common mistakes made by them are the ones resulting from he fact that they solved the questions as if there were no absolute value. In their study entitled detection of the difficulties experienced by the elementary school students in absolute value, Yenilmez and Avcu(2009) performed a test composed of open-ended questions on 8thgrade students. As a result of the study, it was detected that the students experienced difficulty in the absolute value of expressions with letters and equation questions that contained absolute value. In the study which was performed on the first-year students who study elementary school mathematics teaching. Today, it is evident that there are various factors that obstruct students' learning and these factors are compiled in three basic sections as sociological, psychological and cognitive. The aim of this study is to detect the learning difficulties of the secondary school students in equation and inequality that contain terms with absolute values in terms of cognitive factors rather than sociological and psychological factors.

Mostly in every level of education; elementary school (known as SD), junior high school (known as SMP/MTsN) senior high school or vocational high school (known as SMA/SMK/MA) and the like, they tend to view mathematics as a terrifying as well as difficult and boring subject. The observation result conducted by the researcher at MTsN Durian Tarung indicates that teacher tend to dominate the class situation and tend to use less media in mathematics learning. The object of mathematics learning is still in abstract form and yet is not supported with an appropriate and attractive media of mathematics learning.

Furthermore, students tend to perform unexpected behaviors during teaching and learning process. The students are obstructing their peers, lots out of class permission, drawing or just doing nothing on their desk. Thus, the low attention display by the students during mathematics and learning process along with the difficulty they face in comprehending the learning material are obstacles experienced by the teacher to achieve the learning goal.

Some students interview result revealed that they find it truly hard to comprehend mathematics since it is identical to numbers, formula and calculation in which according to them is a confusion. These lead them to boredom and less focus in learning mathematics particularly toward material which requires comprehension, analysis and thoroughness.

In addition, teacher also has not yet rely on the use of varying and interesting learning media. Usually, teacher rely heavily on board, marker, Students Activity Sheet (known as LKS) and text book. It is suspected that all these old-fashion media are fail to promote the improvement of students' interest in mathematics learning, so that it may cause the students to think that mathematics is a hard and boring subject. 
These problems indicate that most of students accomplishment has not yet achieved minimum criteria of mastery learning (known as KKM. One of the main reason for the students to have a low interest toward mathematics learning is non-varying media utilization. It is against the fact that today the use of media or aids in learning process has improved rapidly. Therefore, the existence of alternative learning media to motivate students to learn mathematics is of vital importance. The selection of appropriate learning media need to fulfill requirements, namely in line with the learning material, the ease to use the media, and attractive for the students, so that optimum learning goal can be achieved.

Mulyasa(2006) stated that "the selection of inappropriate or irrelevant learning media may result in students low comprehension toward the target material as this may also distract the development of students' individual competence". There are three kinds of learning media: graphic media, audio media, and audio visual media. One of the learning media employed is comic media which is part of graphic media. According to Sudjana \& Rivai (2013) comics is define as one of the cartoon form which reveal a character and play a plot in a tight sequence and is a picture related which designed to entertain the reader. In this case, the comics is a particular comics with mathematics content. Rohani (1997) stated that comics media is a simple, easy, specified and in personal to comprehend, hence it is informative and educative. Comics is a learning media which facilitates learning core. This kind of media may trigger students motivation in learning since the media being used is interesting and fun.

Thus, may motivate the teachers to search for a more communicative way in teaching mathematics to the student. In doing so, mathematics teacher may actually refer to the research conducted by Richard (2006). Though the research is focus on language teaching, but the tone is actually no different. This research suggested that teacher should be aware about their very own understanding toward certain approach since this may lead to misconception and wrong practice in teaching and learning activity.

In addition, the research conducted by Jacobs \& Farrell (2003) also revealed specific points or aspects of communicative language teaching. In case, teacher finds it hard to comprehend this issue or confuse about the point where to begin with, the detail explanation served by these two researchers would ease the teacher. Moreover, Littlewood (2014) hinges on reflection on teachers teaching attitude and perception for both in today situation and the future time. It is expected that these would contribute toward a better result on mathematics learning particularly. Finally, Canagarajah (2014) suggested that learning is long life learning. The keywords are movement and innovation. And so, this is why employing comic as a mathematics learning media is of vital importance.

Pardimin and Widodo (2017) states that Learning devices are tools or equipment to carry out the process that will enable educators and learners perform the learning activities. Learning media is one of the learning tools that support the success of the learning process. Mathematics comic media may help students' comprehension process of learning material since it in the form of comics along with the appropriate story. Mathematics comic media can also support the teaching method employed by the teacher, so that learning process can be more effective and efficient. The purpose of this research is to produce mathematics comic media which fulfil validity and practicality criteria. The result shows that the designed media is valid and practical. Tin Lam Toh proposes the use of cartoons and comics, which are usually enjoyed by school-going children, in teaching algebra. Feedback from teachers showed that their students became more motivated to learn the subject through the use of cartoons and comics in algebra lessons. The teachers were able to engage their students in the process of learning elementary algebra. Mathematics comics media may help students' comprehension process of learning material since it in the form of comics along with the appropriate story. 
Mathematics comics media can also support the teaching method employed by the teacher, so that learning process can be more effective and efficient. The purpose of this research is to produce mathematics comics media which fulfill validity and practicality criteria.

\section{METHOD}

This research was a research and development employing the 4-D model by Thiagarajan and Semmel (1974). The model consisted of four development stages, namely define, design, develop and disseminate. This research development was only in 3 step. Define is to determine and define the requirements need to develop comics media. This stage is also to analyze the goal and limitation of the developed learning material. Next, design step is to pay attention on three product characteristics, namely: content, interface and support. At the develop step, formative evaluation is take place. It is consist of prototyping stage (self evaluation, expert reviews, one-to-one evaluation and Small Group).

The try out subject of this research was six students of class VII MTsN Durian Tarung Padang and two mathematics teachers. The research data is qualitative and quantitative. Qualitative data is obtain from the observation result and interview. Meanwhile, quantitative data is obtain from validation sheet. The research instruments are 1) device validation sheet. 2) practicality test sheet. Data analysis techniques are 1) analysis data which is obtain from observation sheet and interview guidance. 2) data analysis is obtain from validation sheet. Assessment score toward validity is using likert scale.

\section{RESULT FINDING AND DISCUSSION}

The research product specification are:

1. The comics story is not repeated in the same sub topic

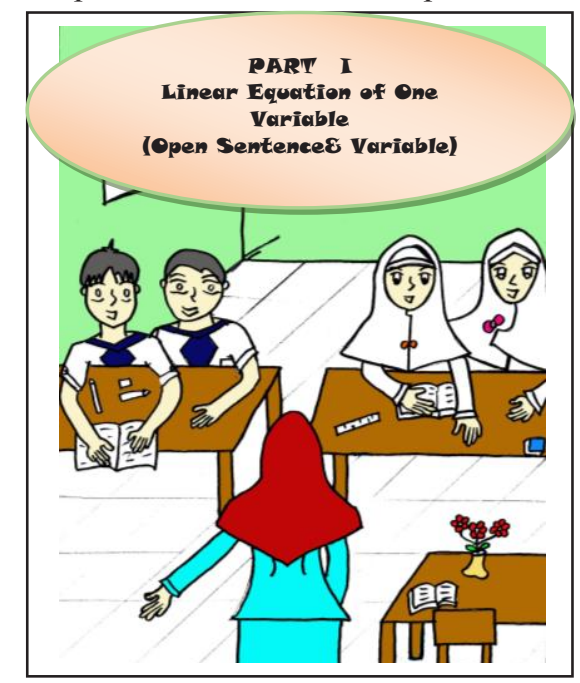

Fig. 1. The Topic of linear equation

2. The title for each sub topic is different from one another. Each of the sub topic is in different theme.

The story of the comics shows linear equation of one variable that will be learned by the students. The story will be divided into some sub topics:

- Sub Topic I : Getting to Know Open Sentence and Variable 
- Sub Topic II : Solving the Linear Equation of One Variable

- Sub Topic III : Solving the linear inequalities of One Variable

- Sub Topic IV : Create and Solve the Linear Equation Model of One Variable

- Sub Topic V : create and Solve the inequalities of One Variable

3. The mathematics comics comes in color and the language being used is the daily-life language used by the students, so that the students may find it easier to comprehend the learning material.

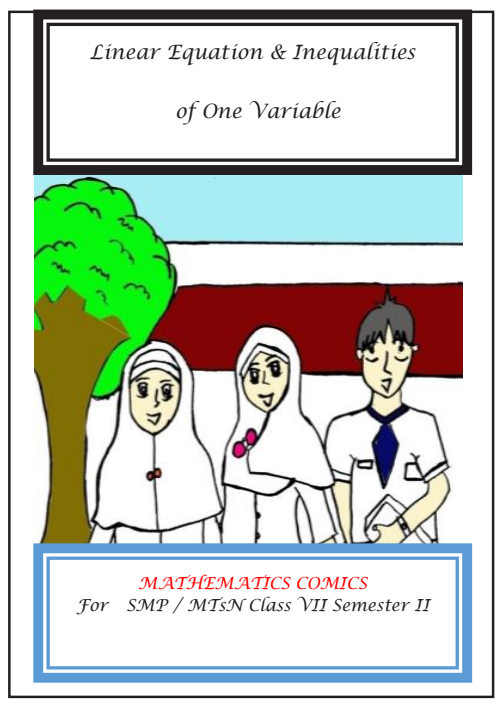

Fig. 1. Cover of comic

4. Consist of conclusion sheet. This sheet will be fulfilled by the students with the conclusion they obtained after learning the material.

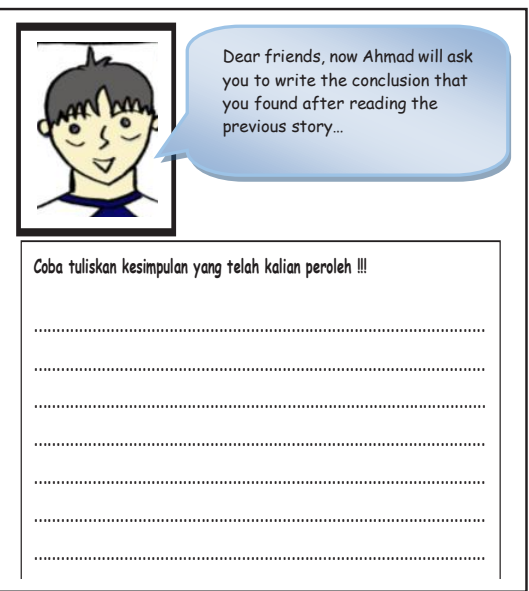

Fig. 2. Student sheet activity

5. Consist of varied exercise to challenge the students to solve.

\section{Exercise}

1. Which one of the following is the linear equation of one variable?
a) $2 \mathrm{x}-4=8$ 


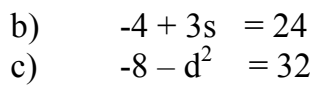

2. Find the linear equation of question number 1 !

3. Find the compilation solution of this following linear equation.

a) $7 \mathrm{a}+3=0$

b) $5 m+4=2 m+16$

4. Find the compilation solution of linear equation $2 \mathrm{a}-100=20$, if:

a) $a$ is an odd number

b)a an even number

\section{Good Luck}

Fig. 2. Caption of the Figure 1. Below the figure

The designed comics were be validated by mathematics expert which consist of four validator. The validation result of mathematics comics media can be seen at table 1 as follow:

Table 1 Mathematics Comics Media Validation Result

\begin{tabular}{|c|l|c|}
\hline No & \multicolumn{1}{|c|}{ Aspect } & Score \\
\hline 1 & Content appropriateness & $83.33 \%$ \\
\hline 2 & Language & $87.50 \%$ \\
\hline 3 & Display & $85.41 \%$ \\
\hline 4 & Graphics & $88.75 \%$ \\
\hline \multicolumn{2}{|c|}{ Average } & $86.25 \%$ \\
\hline
\end{tabular}

The result of mathematics comics media validation displayed on table 1 is valid in criteria. It can be seen from the average score of validity for comics media as $86.25 \%$. every component has validity score between $80 \%$ - 89\%. It implies that every aspects of mathematics comics is valid. Next, the practicality of mathematics comics media from the students' point of view can be obtained from the practicality questionnaire result that is distributed toward some students as can be seen in table 2 .

Table 2.The Result of Mathematics Comic Media Practicality

\begin{tabular}{|c|l|c|}
\hline No & \multicolumn{1}{|c|}{ Aspect } & Score \\
\hline 1 & The ease of the use & $86.80 \%$ \\
\hline 2 & Time effectiveness & $89.58 \%$ \\
\hline 3 & Advantage and fascinate & $93.75 \%$ \\
\hline \multicolumn{2}{|c|}{ Average } & $90.04 \%$ \\
\hline
\end{tabular}

Table 2 shows that according to the students, mathematics comics media is practical in its every aspect with the average score is $90,40 \%$. Mathematics comics media Practicality media according to the teacher is obtain from practicality questionnaire result that can be seen on table 3 . 
Table 3.The Result of Mathematics Comic Media Practicality

\begin{tabular}{|c|l|c|}
\hline No & \multicolumn{1}{|c|}{ Aspect } & Score \\
\hline 1 & The easy of the use & $85.42 \%$ \\
\hline 2 & Time effectiveness & $87.50 \%$ \\
\hline 3 & Advantage and fascinate & $80.00 \%$ \\
\hline \multicolumn{2}{|c|}{ Average } & $84.31 \%$ \\
\hline
\end{tabular}

Table 3 shows that according to the teacher, mathematics comics media is practical in its every aspect with the average score is $84.31 \%$. Based on the research finding, it can be concluded that the result of mathematics comics media development on linear equation $\&$ inequalities of one variable at class VII Yunior High School (SLTP/MTs) Padang is valid and very practical to be used as mathematics learning media. The resulted mathematics comics media obtain $86.25 \%$ validity result with valid criteria by validator. In whole, the practicality score given by the students is $90.04 \%$ with very practical category. Meanwhile, total practicality score by both teacher and students is $85 \%$ with practical category.

\section{CONCLUSION}

Based on the research finding, it can be concluded that the result of mathematics comic media development on linear equation \&inequalities of one variable at class VII Yunior High School (SLTP/MTs) Padang is valid and very practical to be used as mathematics learning media. The resulted mathematics comic media obtain $86.25 \%$ validity result with valid criteria by validator. In whole, the practicality score given by the students is $90.04 \%$ with very practical category. Meanwhile, total practicality score by both teacher and students is $85 \%$ with practical category.

It is recommended for future researcher to dig and explore more on this topic by employing qualitative research method. The future researcher may also invite the participants such as the students and the teacher to work together and participate actively in the research in order to obtain a better understanding toward this particular topic. The future researcher may also refer to the research conducted by Sato \& Kleinsasser (1999) who put its participants as the main resources for the research. As the result, a more comprehensive research result is attained. To be precise in doing this kind of recommended research, the future researcher can consult Heigham and Juanita's (2009) book.

\section{REFERENCES}

1. Ahmad Rohani. (1997). Media Instruksional edukatif. Jakarta: PT Rineka Cipta.

2. Baştürk, S. (2009). Student teachers' approaches to student's mistakes in the case of the absolute value concept. Necatibey Faculty of Education Electronic Journal of Science and Mathematics Education,3(1),174-194.all, D. (1993). Students' difficulties incalculus, proceeding of working group 3 on students' difficulties in calculus. ICME-7, Qoubec, Canada

3. Canagarajah, S. (2014).In search of a new paradigm for teaching English as an international language.TESOL Journal, 5(4), 767-785.

4. Coşkun, O. (2008). Diagnosing learning difficulties in modular arithmetic. Unpublished Master Thesis.Atatürk University Graduate School of Natural and Applied Sciences Departman of Mathematics Education,

5. Durmuş, S. (2007). Matematikte öğrenme güçlüğü gösteren öğrencilere yönelik öğretim yaklaşımları. Mehmet Akif Ersoy Üniversitesi Eğitim Fakültesi Dergisi, 76-83 
6. Ersoy, Y. \&Ardahan, H. (2003). İlköğretim okullarında kesirlerin öğretimi-II: Tanıya yönelik etkinlikler düzenleme. -Available at

http://www.matder.org.tr/index.php?option=com content\&view=article\&id=64:ilkogretim-okul larinda-kesirlerin-ogretimi-ii-taniya-yonelik-etkinlikler-duzenleme\&catid=8:matematik-kosesimakaleleri\&Itemid $=172$

7. Harel, G. (1989). Learning and teaching linear algebra: Difficulties and an alternative approach to visualizing concepts and processes. Focus on Learning Problems in Mathematics, 11(2), 139-148.

8. Heigham, Juanita, Dr; Croker, Robert A., Dr (2009). Qualitative Research in Applied Linguistics: A Practical Introduction. Retrieved from http://www.eblib.com

9. Keşan, C., Kaya, D.,\& Güvercin S. (2010). The effect of problem posing approach to the gifted student's mathematical abilities, International Online Journal of Educational Sciences, 2 (3), 677-687

10. Jacobs, M. G, \& Farrell, T. S. C. (2003).Understanding and implementing CLT (Communicative Language Teaching) Paradigm.RELC Journal, 34(1), 5-30.

11. Littlewood, W. (2014). Communicative-oriented language teaching: where are we now? Where do we go from here? Language Teaching, 47(3), 349-362.

12. Mulyasa, E. (2006). Kurikulum yang Disempurnakan Pengembangan Standar Kompetensi dan Kompetensi Dasar. Bandung: PT. Remaja Rosdakarya..

13. Nana Sudjana dan Ahmad Rivai. (2013). Media Pengajaran. Bandung: Sinar Baru Algesindo.

14. Özmantar, M. F., Bingölbali, E. \&Akkoç, H. (2008). Matematiksel kavram yanılgıları ve çözüm önerileri.Ankara: Pegem Akademi.

15. Pardimin and Sri Adi Widodo (2017). Development Comic Based Problem Solving in Geometry. IEJME-Mathematics Education Vol.12, No.3, 233-241

16. Rasmussen, C. L. (1998). Reform in differential equations: a case study of students' understandings and difficulties. The Annual Meeting of American Educational Research Association, San Diego, CA. Available at http://eric.ed.gov/ERICDocs/data/ericdocs2sql/content_stroge_01/0000019b/80/15/8e/cb.pdf

17. Richards, J, C. (2006). Communicative Language Teaching Today. Retrieved from https://learn.uq.edu.au/bbcswebdav/pid-1922751-dt-content-rid-9055584 1/courses/SLAT7826 S/Richards-Communicative-Language.pdf

18. Sato, K., \&Kleinsasser, R, C. (1999). Communicative Language Teaching (CLT): Practical understanding. The Modern Language Journal, 83 (4), 494-517.

19. Tall, D. O. \&Razali, M. R. (1993). Diagnosing students' difficulties in learning mathematics. International Journal of Mathematical Education in Science and Technology, 24(2), 209-222

20. Thiagarajan, Semmel \& Semmel. (1974). Instructional Development for Training Teachers of Exceptional Children. A sourcebook. Central for Innovation on the Handicapped: Bloomington Indiana

21. Tin Lam Toh . Use of Cartoons and Comics to Teach Algebra in Mathematics Classrooms. National Institute of Education, Nanyang Technological University, Singapura

22. Ural, A. (2006). Conceptual obstacles concerning the learning of the function. Ege Eğitim Dergisi,7(2),75-94.

23. Yenilmez, K. \&Avcu, T. (2009). Primary School Students' difficulties in Learning Absolute Value. Dicle Universitesi Ziya Gokalp Egitim Fakultesi Dergisi, 12, 80-88. 